\title{
ANTIOXIDANT ACTIVITY AND SENSORY PROPERTIES CARROT (Daucus carrota) SOYGHURT
}

\author{
Enny Karti Basuki Susiloningsih, Ulya Sarofa, Fauziah Imroatus Sholihah \\ University of Pembangunan Nasional "Veteran" East Java, Surabaya, Indonesia \\ E-Mail : ennykartibasuki@gmail.com
}

\begin{abstract}
Carrot (Dascus carota L.) is one of the more commonly used vegetables of human nutrition. It is rich in beta carotene, ascorbic acid, tocopherol and classified as vitaminized food. Combination of carrot juice and yoghurt produce a nutritionally balanced food. The aim of this study is to determine the best combination of carrot juice concentration and was fermentation duration. soyghurt was prepared in the laboratory scale production from soymilk and carrot juice was fermented with Streptococcus thermophillus and Lactobacillus bulgaris. Carrot soyghurt was prepared by blending soymilk with 10, 15 and 20\% carrot juice before fermentation 14, 16 and 18 hours. The carrot soyghurt produced from $15 \%$ carrot juice and 16 hours fermentation were accepted of panelists, having 140 of taste score, 104 of flavour score, 118 of color score and 94.5 of viscocity, $6.52 \%$ of protein content, $1.51 \%$ of fat content and $52.49 \%$ of activity antioxidant.
\end{abstract}

Keywords: antioxidant activity, sensory properties, fermentation, carrot soyghurt

\section{INTRODUCTION}

The oxidative damage caused by free radicals and other reactive oxygen species plays a significant pathological role in human diseases (Wang et al., 2006). Among these diseases cancer has an important place. According to observational epidemiological studies, diets containing mainly fruits and vegetables are related to a lower cancer incidence, especially cancers from the gastrointestinal tract. This is due in part to the dietary antioxidant content of fruit and vegetables (Serrano et al., 2007). So it is clear that natural antioxidant from foods may reduce the oxidative damage on human body (Lin and Yen, 1999).

Soymilk has a high amount of protein, iron, unsaturated fatty acids and niacin, but it is low in fat, carbohydrates, calcium. It has little saturated fat and no cholesterol, hence it is known to reduce the risk of heart disease (Kim et al., 2006, Jinapong et al., 2008). It is safe for people with lactose intolerance or milk allergy and for children with galactosemia. However, the beany flavor due to the presence of aldehydes and alcohols and flatulence caused by indigestible oligosaccharides limit the widespread consumption of soymilk (Blagden and Gilliland, 2005, Yang and Zhang, 2009). Soy-based foods are promising supplements to overcome existing proteincalorie-malnutrition problems (Khare et al., 1994). However, its consumption may lead to digestive problems associated with the presence of raffinose and stachyose. One method of overcoming such problem and also to improve the acceptability is by fermentation (Hati et al., 2013).

Fermentation improves the bioavailability of isoflavones, assists in digestion of protein, provides more soluble calcium, enhances intestinal health, and supports immune system. Soybeans contain the highest concentration of isoflavones, among all foods (Ismail and Hayes, 2005, Kuo et al., 2006). The range of health benefits such as cancer prevention, reduced risk of osteoporosis, valuable role in chronic renal disease, and protection against cardiovascular disorders are claimed to be due to the presence of these isoflavones (Orhan et al., 2007). However, soymilk is the aqueous extract of whole soybeans (Glycine max). Soymilk is considered as a suitable economical substitute for cow's milk and an ideal nutritional supplement for lactose- intolerant population (Dhananjay et al., 2006). Soybeans is a rich source of isoflavones, which are reported to have beneficial estrogenic effects (Adlerereutz, 2002, Brouns, 2002, Corn et al., 2004) with potential bioactive antioxidant properties. Probiotic lactic acid bacteria, when grown in soy milk with whey protein concentrate have the ability to utilize phenolic components producing phytase enzyme and reducing the polyphenol content after fermentation. Free radicals and other reactive oxygen species are generated by exogenous chemicals or endogenous metabolic processes in food systems or human body. The radicals may cause oxidative damage by oxidizing biomolecules and results in cell death and tissue damage (Kehrer, 1993).

Carrot (Dascus carota L.) is one of the more commonly used vegetables of human nutrition. It is rich in beta carotene, ascorbic acid, tocopherol and classified as vitaminized food (Hashimoto and Nagayama, 2004). Combination of carrot juice and yoghurt produce a nutritionally balanced food. Carrots are good source of carbohydrate, calcium, phosphorous, iron, potassium, copper, manganese and sulphur. It is an excellent source of vitamin A, B1, B2, C, E, thiamin, folic acid and riboflavin but lack in protein and fat. Yoghurt is rich in protein and fat but is deficient in iron and vitamin C. Yoghurt is an important dairy product, particularily for consumers with lactose intolerance (Mohamed et al, 2014) Supplementation of yoghurt with selected vegetables will provide additional health properties, especially concerning with antioxidant properties and will result in the development of novel functional dairy products (Lejuo et $a l, 2014)$. Blending of yoghurt with carrot juice would produce a nutritionally rich food (Ikken et al., 1999, Raum, 2003). The intake of carrot as potent antioxidants, appear to be associated with better health. It is not only preventing vitamin A deficiency but also cancer and other diet related human diseases. It has greater cytotoxic effect against cancer cell and reducing the enzymes that promote the conversion of precarcinogens to carcinogens. It may also enhance the immune system, protect against stroke, high blood pressure, osteoporosis, cataracts, arthritis, heart disease, bronchial ashma and urinary tract infections (Beom et al., 1998, Sun et al., 2001, Seo and Yu, 2003). 
Soybeans are the most important food source of isoflavones that exhibit antioxidant activity. Carrots are food source of vitamin C (ascorbic acid), vitamin E (alfa tocopherol) and carotenoids as non enzymatic antioxidants. Combination of carrot juice and soyghurt produced a nutritionaly balanced food and an ideal nutritional supplement for lactose intolerant population. This study was therefore, aimed to find the best combination of carrot juice concentration and its fermentation duration in soyghurt.

\section{METHODOLOGY}

Materials used in this research were soybeans, starters (Lactobacillus bulgaricus and Streptococcus thermophillus), carrot, low fat skimmed milk, sucrose, and aquadest. The equipment used in this research were magnetic stirrer, autoclave, digital balance, centrifuge, spectrophotometer, micro Kjeldahl and several glass tools to support the research.

Preparation of carrot juice used carrot roots were washed thoroughly, skins were removed, peeled by sharp knife and cut longitudinally into halves. These halves were stem blanched for ten minutes to inactivate pectinase and peroxidase enzymes, in order to tenderize the carrot tissues. The juice was obtained by mixer these in blender with sieves. The obtained juice was analyzed for its antioxidant activity using DPPH.

Preparation of soy milk used manufacture of soy milk was started from soybeans sorting and cleaned under running water. Then, they were immersed in water for 8 hours and washed thoroughly. Soybeans were boiled in water with a ratio of 1:8 until it reached temperature of $90^{\circ} \mathrm{C}$. Boiled soybeans were blended until it turned into a mush, then they were filtered to get the soy milk. Furthermore, soy milk as raw material was analyzed for its antioxidant activity using DPPH.

Preparation of inoculum used stock cultures were prepared by mixing nutrient broth grown cultures with sterile, incubation at $37^{\circ} \mathrm{C}$ for 24 hours. As much as $1 \%$ cultures were transfered into $10 \%(\mathrm{w} / \mathrm{v})$ of skim milk, and put into incubation at $37^{\circ} \mathrm{C}$ for 48 hours.

Preparation of carrot soyghurt used soy milk and various concentrate of carrot juice $(10 \%, 15 \%$ and $20 \%$ $\mathrm{v} / \mathrm{v})$ with a total volume $300 \mathrm{ml}$ and added sucrose of $4 \%$ $(\mathrm{w} / \mathrm{v})$, and skim milk of $20 \%(\mathrm{w} / \mathrm{v})$ were homogenated. The mixtures was then pasteurized at $85^{\circ} \mathrm{C}$ for 15 minutes, and cooled to $40-45^{\circ} \mathrm{C}$. Starter was added at the rate of $5 \%$ (L. bulgaricus:S. thermophillus $=1: 1$ ) was homogenized and put in various of incubation (14, 16 and 18 hours) at room temperature. The obtained mixture was analyzed for antioxidant activity using $\mathrm{DPPH}$, whereas fat by AOAC (1990) and protein by AOAC (1990).

Sensory evaluation used twenty panelists student of Food Technology of Faculty of Industrial Technology Indusrty University of Pembangunan Nasional "Veteran" Surabaya Indonesia experience in the use and evaluation of carrot soyghurt. They evaluated $20 \mathrm{~g}$ portions of each carror soyghurt samples using an unstructured hedonic scale 5 with ends anchored, 1 dislike very much and I like very much. The samples were presented at random and individually evaluated by Nelson and Trout (1981).

Statistical analysis was performed using two ways analysis of variance (Anova) and the mean were compared across groups by DMRT and the significant differences were determined at $\mathrm{p}<0.05$.

\section{RESULTS AND DISCUSSION. \\ Activity Antioxidant of Raw Materials}

The antioxidant activity of soy milk, carrot juice and soyghurt were $13.72 \%, 8.35 \%$ and $32.83 \%$, respectively. Bioactive compounds presented in soybeans varied greatly with the cultivar, weather and geographical sowing location (Hoeck et al., 2000, Seguin et al., 2004), which was similar to that of bioactive of carrot.

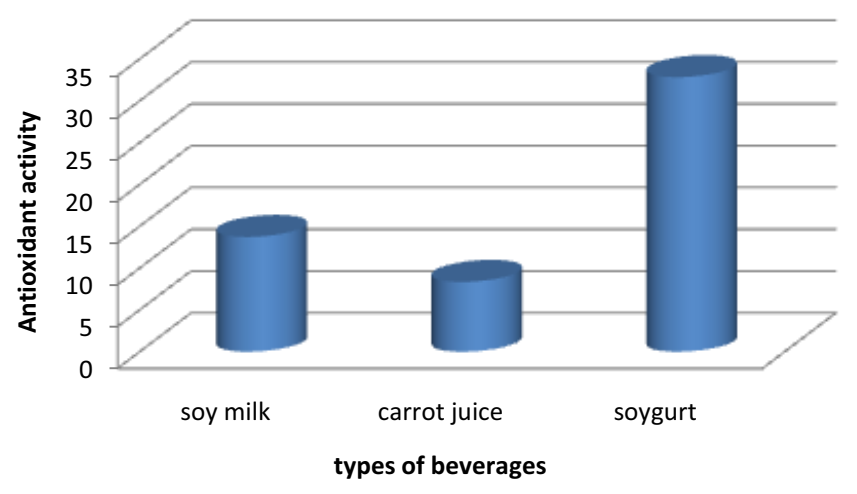

Figure-1. antioxidant activity of soymilk, carrot juice and soygurt

\section{Protein content}

The total of protein content in carrot soyghurt ranged from 6.745 to $6.34 \%$ for increased fermentation time and from $6.63 \%$ to $6.45 \%$ for increased concentration of added carrot juice. Protein content of carrot soyghurt had no significant different $(\mathrm{p}>0.05)$, were presented in Table 1.. Protein decreased during fermentation time and increased concentration of added carrot juice in carrot soyghurt. It was found that the curd tention rate decreased with the increased of the concentration of added carrot juice, on contrary, the protein decreased with the increased fermentation time and increased of added concentration juice carrot. A nearly similar finding was reported by Galal et al. (2003). Probiotic organisms are rich in proteolytic activity, and increase free amino acid content in carrot soyghurt. 
Table-1. Protein carrot soyghurt.

\begin{tabular}{cccc}
\hline Fermention time $(\mathrm{h})$ & Total protein $(\%)$ & Carrot juice $(\%)$ & Total protein $(\%)$ \\
\hline 14 & 6.74 & 10 & 6.63 \\
16 & 6.47 & 15 & 6.49 \\
18 & 6.34 & 20 & 6.45 \\
\hline
\end{tabular}

Reactive oxygen species can cause fragmentation of the peptide chain, alteration of electrical charge of proteins, cross-linking of protein, and oxidation of specific amino acids and therefore lead to increased susceptibility to proteolysis by degradation by specific proteases (Kelly and Mudway, 2003). There are many proposed mechanisms for the therapeutic effects of isoflavones, including inhibition of protein tyrosine kinase, binding to estrogen receptors, inhibition of production of reactive oxygen species (Wei et al., 1995).

\section{Total fat and activity antioxidant}

Total fat content in carrot soyghurt ranged from $1.19 \%$ to $1.92 \%$ and antioxidant activity from $30.07 \%$ to $60.72 \%$ for increased concentration of added carrot juice and time fermentation. Total fat of carrot soyghurt decreased for added concentration of carrot juice and increased fermentation time which has a significant different $(\mathrm{p}<0.05)$ in carrot soyghurt (Table 2). Probiotic organisms are rich in lipolytic activity, increased free fatty acid content in carrot soyghurt. Lipid soluble vitamin $\mathrm{E}$ is concentrated in the hydrophobic interior site of cell membrane and is the principal defence against oxidant induced membrane injury. Vitamin E donates electron to peroxyl radical, which is produced during lipid peroxidation. A-Tocopherol is the most active form of vitamin $\mathrm{E}$ and major membrane bound antioxidant in cell. Vitamin E triggers apopsis of cancer cells and inhibits free radical formations (White et al., 1997). Reactive oxygen species can induce lipid peroxidation and disrupt the membrane lipid bilayer arrangement that may inactivate membrane-bound receptors and enzymes and increase tissue permeability (Girotti, 1985). Products of lipid peroxidation,such as malondialdehyde and unsaturated aldehydes, are capable of inactivating many cellular proteins by forming protein cross linkages (Montuschi, et al.,2000, Morrison et al., 1999, Nowak et al., 1999). Activity antioxidant of carrot soyghurt increased for concentration of added carrot juice, also fermentation time increased and was statistically significant $(p<0.05)$ in carrot soyghurt. Flavonoids are considered as phenol compounds with highest antioxidant activity due to their chemical structure. Among dietary flavonoids, isoflavones, especially genistein, shown one of the highest antioxidant activities ( Heim et al., 2002).

Table-2. Fat and antioxidant activity of carrot soyghurt.

\begin{tabular}{|c|c|c|c|}
\hline Carrot juice ( \%) & Fermentation time $(\mathrm{h})$ & Total fat $(\%)$ & Antioxidant activity (\%) \\
\hline \multirow[t]{3}{*}{10} & 14 & $1.92^{\mathrm{f}}$ & $30.07^{a}$ \\
\hline & 16 & $1.85^{\mathrm{f}}$ & $42.97^{\mathrm{b}}$ \\
\hline & 18 & $1.70^{\mathrm{e}}$ & $46.65^{\mathrm{c}}$ \\
\hline \multirow[t]{3}{*}{15} & 14 & $1,70^{\mathrm{f}}$ & $50.32^{\mathrm{d}}$ \\
\hline & 16 & $1.51^{\mathrm{cd}}$ & $52.49^{\mathrm{e}}$ \\
\hline & 18 & $1.42^{\mathrm{c}}$ & $55.20^{f}$ \\
\hline \multirow[t]{3}{*}{20} & 14 & $1.57^{\mathrm{d}}$ & $57.03^{\mathrm{g}}$ \\
\hline & 16 & $1.32^{\mathrm{b}}$ & $59.09^{\mathrm{h}}$ \\
\hline & 18 & $1.19^{\mathrm{g}}$ & $60.72^{\mathrm{i}}$ \\
\hline
\end{tabular}

The same letter in the same column indicates no significant differences.

The inhibition of ascorbate autoxidation observed with soymilk may be attributed to the action of isoflavones and tocopherols, the main phenols found in soybean (Persky and van Horn, 1995). On the other hand, liberation of aglycone genistein and diadzein through the catalytic action of beta glucosidase during fermentation (Chien, 2004) and the intracellular antioxidants of starter organism (Lin and Yen, 1999) may account for the increased ascorbate-autoxidation inhibition found with the fermented soymilk. To prepare the probiotic fermented soy curd, previously found that the bifidobacteria and lactic acid bacteria were beneficial to each other when grown simultaneously (Wang et al., 2002). Water soluble vitamin C (ascorbic acid) provides intracellular and extracellular aqueous phase antioxidant capacity primarily by scavenging oxygen free radicals. It converts vitamin $\mathrm{E}$ free radicals back to vitamin E. Its plama levels have shown to decrease with age (Bunker, 1992, Mezzetti et al., 2006). Carotenoids are pigments found in plants. Primarily, ß-carotene has been found to rect with peroxyl, hydroxyl and superoxide radicals. Carotenoids show their antioxidant effects in low oxygen partial pressure but may have pro-oxidant effects at higher oxygen concentration (Rice et al.,1997). Both carotenoids and retinoic acid are capable of regulating transcription factors (Niles, 2004).

\section{Organoleptic of carrot soyghurt}

Sensory properties of carrot soyghurt were evaluated for the flavor, color, viscosity and taste. Flavor ranged from 88 to 109 , color from 46 to 150 , viscosity from 66 to 132.5 and taste was from 74 to 155.5 for increased concentration of added carrot juice and time fermentation in carrot soyghurt. The effect of fermentation time and carrot juice level on these total score flavor, color, viscosity and taste were significant different ( $\mathrm{p}$ $<0.05$ ) (Table 3). 
Table-3. Organoleptic examination of carrot soyghurt.

\begin{tabular}{cccccc}
\hline Carrot juice (\%) & $\begin{array}{c}\text { Fermentation time } \\
\text { (h) }\end{array}$ & $\begin{array}{c}\text { Total score of } \\
\text { flavor }\end{array}$ & $\begin{array}{c}\text { Total score of } \\
\text { color }\end{array}$ & $\begin{array}{c}\text { Total score of } \\
\text { viscosity }\end{array}$ & $\begin{array}{c}\text { Total score of } \\
\text { taste }\end{array}$ \\
\hline \multirow{2}{*}{10} & 14 & 95 & 48 & 132.5 & 155.5 \\
& 16 & 97 & 46 & 132.5 & 129.5 \\
15 & 18 & 92 & 55 & 137 & 129.5 \\
& 14 & 88 & 81 & 128.5 & 108.5 \\
20 & 16 & 104 & 118 & 94.5 & 75 \\
& 18 & 109 & 124.5 & 66 & 79 \\
& 14 & 108.5 & 132.8 & 67 & 74 \\
\hline
\end{tabular}

Product of Lactobacillus bulgaricus such as flavor and Streptococcus thermophillus such as taste carrot soyghurt. Taste was cause by lactic acid, acetaldehyde and volatile compound producing bacteria. The addition of $15 \%$ carrot juice to soymilk showed to be the best concentration as it got the highest evaluation mark during the 18 hours fermentation. It implies no unpleasant odor, a pleasant level of acidity and pleasing balance of flavor during the fermentation period. Color score increased for concentration of added carrot juice and time fermentation carrot soyghurt. The color of carrot soyghurt was caused by $ß$-caroten. With increased concentration of added carrot juice and along the fermentation time in carrot soyghurt, color of carrot soyghurt became a thick orange. Viscosity score decreased for concentration of added carrot juice and increased time fermentation. The addition of $10 \%$ carrot juice to soymilk showed to be the best concentration as it got the highest evaluation mark during the 14 hours fermentation.

\section{CONCLUSIONS}

The results of the present investigation are of pratical value.The increase in the concentration carrot juice and fermentation time gave significant effect on reducing fat content and viscosity while increasing antioxidant activity, flavor, color and taste increased and does not have significant effect on protein content. With the carrot juice's concentration of $15 \%$ and fermentation time of 16 hours, carrot soyghurt can be considered acceptable.

\section{REFERENCES}

Adlercreutz H. 2002. Phyto-oestrogens and cancer, Lancer Oncology 3: 364-373.

Beom J., Young S. and Myung H. 1998. Antioxidant activity of vegetables and blends in iron catalyzed model system, J. Fppd Sci. and Nutr. 3: 309-314.

Blagden T. and Gilliland S. 2005. Reduction of levels of volatile components associated with the beany flavor in soymilk by Lactobacilli and Streptococci, Journal of Food Science: Food Microbiologyand Safety 70(3): 70-76.

Brouns F. 2002. Soya isoflavones: a new and promising ingredient for the health foods sector, Food Research International 35: 187-193.

Bunker V.W. 1992. Free radicals, antioxidants and ageing, Medical Laboratory Science 101: 3780-3785.
Chien H.I. 2004. Change of isoflavones contents in cultured soymilk fermented with lactic acid bacteria and bifidobacteria, M.S. Thesis, National Taiwan University, Taipei, Taiwan.

Corn Well T., Cohick W. and Raskin I. 2004. Phytoestrogen and human health effects, Phytochemistry 65: 995-1016.

Davies K.J. 1987. Protein damage and degradation by oxygen radicals. I General aspects, Journal of Biological Chemistry 262: 9895-9901.

Dhananjay S., Kulkarni, S. S., Kapanoor K. G., Naganagouda V. K. and Veerappa H. M. 2006. Reduction of flatus-inducing factors in soyilk by immobilized agalactosidase, Biotechnology and Applied Biochemistry 45: 51-57.

Galal E.A., Mahmoun A., El-Fakhany A. and Moawad A. 2003. Effect of adding carrot puree on organoleptic, chemical and microbiological quality, Proc. The $1^{\text {st }}$ International content Food for Better Health, NRC, 18-20 October (2003), Cairo, Egypt.

Girotti A.W.1985. Mechanisms of lipid peroxidation in vivo and in vitro, Journal Free Radicical Biology and Medicine 1: 87-95.

Hahimoto, T. and Nagayama T. 2004. Chemical composition of ready to eat fresh carrot, Journal of The Food Hygienic Society of Japan 39: 324-328.

Hati, S., Vij, S., Mandal, S., Malik, R.K., Vandna, 2013, $\alpha$-Galactosidase activity and oligasacharides utilization by probiotic lactobacilli during fermentation of Soy Milk, Journal of Food Processing and Preservation (doi. 10.1111/jfpp.12063).

Hoeck J.A., Fehr W.R. Murphy P.A. Welke G.A. 2000. Influence of genotype and environment on isoflavone contents of soybean, Journal Crop Science 40: 48-51.

Heim K.E., Tagliaferro A.R. and Bobilya, D.J. 2002. Flavonoid antioxidants: Chemistry, metabolism and structure activity relationships, The Journal of Nutritional Biochemistry 13: 572-584.

Ikken Y., Cambero I., Marin M., Martner A., Hars I. and Morales P. 1998. Antimutagenic effect of fruit and vegetable aqueous extracts against N-nitrosamine 
evaluated by the Amestest, Journal of Agricultural and Food Chemistry 1: 353-376.

Ismail B. and Hayes K. 2005. B-glucosidase activity toward different glycosidic forms of isoflavones, Journal of Agricultural and Food Chemistry 53: 4918-4924.

Jinapong N., Suphanthaarika M. and Jamnong P. 2008 Production of instant soymilk powders by ultrafiltration, spray drying and fluidized bed agglomeration, Journal of Food Engineering 84: 194-205.

Kehrer J.P. 1993. Free radicals as mediators of tissue injury and disease, Critical Reviews Toxicology 23: 21-48.

Kelly F.J. and Mudway I.S. 2003. Protein oxidation at the air-lung interface, Amino Acids, 25: 375-396.

Khare S.K., Krishna J. and Manishwara M.N. 1994. Hydrolysis of flatulence-causing oligosaccharides by agarose-entrapped Aspergillus oryzae cells, Biotechnology and Applied Biochemistry 19: 193-198.

Kim S., Berhow M., Kim J.,Chi H., Lee S. and Cheng I. 2006. Evaluation of soyasaponin, isoflavone, protein, lipid and free sugar accumulation in developing soybean seeds, Journal of Agricultural and Food Chemistry 54: 1000310010 .

Kuo I., Cheng W., Wu R., Huang C. and Lee K. 2006. Hydrolysis of black soybean isoflavone glycosides by Bacillus subtilis natto, Biotechnological Products and Process Engineering 73: 314-320.

Lejuo D.N., Tadecesz G. and Matgorxata T. 2014. Yoghurts with addition of selected vegetables : Acidity, antioxidant properties andsensory quality, Acta Scientiarum Polonorum Technologia Alimentaria 13(1) $35-42$.

Lin M.Y. and Yen C.L. 1999. Antioxidative ability of lactic acid bacteria, Journal of Agricultural and Food Chemistry 47: 1460-1466.

Menzzetti A., Lapenna D., Romano F., Costantini F. and Piendomenico S.D. 1996. Systemic oxidative stress and its relationship with age and illness, Journal of The American Geriatries Society 44: 823-827.

Mohamed A.G., Abeer F.,Zayan, Nadia and Shalulin M. 2014. Physiochemical and Sensory evaluation of youghurt fortified with dietary fiber and phenolic compounds, Journal of Life Science 11(9) 816-822.

Montuschi P., Collins J.V., Ciabattoni G., Lazzeri N., Corradi M., Kharitonov S.A. and Bames P.J. 2000. Exhaled8-isoprostane as an in vivo biomarker of lung oxidatiye stress in patients with COPD and healthy smoker, American Journal of Respiratory Critical Care Medicine162: 1175-1177.

Morrison D., Rahman L., Lannan, S. and Max Nee W. 1999. Epithelial permeability, inflammation, and oxidant stress in the air spaces of smokers, American Journal of Respirratory and Critical Care Medicine159: 473-479.

Niles R.M. 2004. Signaling pathways in retinoid chemoprevention and treatment of cancer, Mutation Research 555: 81-96.

Nowak D., Kasielski M., Pietras T. and Bialasiewicz P. 1999. Increased content of thiobarbituric acid reactive substances and hydrogen peroxide in the expired breath condensate of patients with stable chronic obstructive pulmonary discase no significant effect of cigarette smoking, Journal Respiratory Medicine 93: 389-396.

Orhan I., Ozcelik B., Kartal M., Aslan S., Sener B. and Ozguven M. 2007. Quantification of daidzein, genistein and fatty acids in soybeans and soy sprouts, and some bioactive studies. Acta Biological Cracoviensia Series Botanica 49: 61-68.

Persky V. and Van Horn. 1995. Epidemiology of soy and cancer perspectives and directions, Journal of Nutrition 125: 709-712

Raum R.,2003, Microbiological quality of health food and organic foods, Journal Netherland Milk and Dairy 14: $130-134$.

Rice-Evans C.A., Sampson J., Bramley P.M. and Holloway D.E.1997. Why dowe expect carotenoids to be antioxidants in vivo?, Free Radical Research 65: 381-398.

Seguin P., Zheng W., Smith D.L.and Deng W.,2004. Isoflavone content of soybean cultivar grown in castern Canada, Journal Science Food and Agricultural 84: 13271332.

Seo A. and $\mathrm{M} \mathrm{Yu}$. 2003. Toxigenic fungi and mycotoxins,In: hand book of industrial mycology (Andrea, $Z$ ed.) Academic Press London, p: 233-246.

Serrano J., Goni I. and Sauro-Calixto F. 2007. Food antioxidant capacity determined by chemical methods may underestimate the physiological antioxidant capacity, Food Research International 40: 15-21.

Sun M.S., Mihyang K. and Song J.B. 2001. Cytotoxicity and quinine reductase induced effects of Daucas carrot leaf extracts on human cancer cells, Kor. Journal of Food Science 30: 86-91.

Wang Y.C., Yu R.C. and Chou C.C. 2002. Growth and survival of bividobacteria and lactic acid bacteria during the fermentation by $\beta$-galactosidase from Mortierella vinacea. Entrapment of $\beta$-galactosidase within polyacryamide gel, Journal of Food Science 41: 173-175.

Wei H., Bowen R., Cai Q. 1995. Antioxidant and antipromotional effects of the soybean isoflavone genistein, Proceeding of the Society for Experimental Biology and Medicine 208: 124-130.

White E., Shannon J.S. and Patterson R.F. 1997. Relationship between vitamin and calcium supplement use 
and colon cancer. Cancer Epidemiol Biomarkers and Prevention 6: 769-774.
Yang H. and Zhang I. 2009. Changes in some components of soymilk during fermentation with the basidiomycete Ganoderma lucidum, Food Chemistry 112: 1-5. 